\title{
PKM : SOSIALISASI PEMANFAATAN SAMPAH ORGANIK DI SEKOLAH DASAR NEGERI 1 PEREAN KANGIN, BATURITI, TABANAN, BALI
}

\author{
Ni Putu Suci Meinarni, Komang Redy Winatha, I Putu Pedro Kastika Yasa, Arya Aditya \\ Widya Semara \\ STMIK STIKOM Indonesia, Bali, Indonesia \\ E-mail: sucimeinarni@stiki-indonesia.ac.id
}

\begin{abstract}
SD Negeri 1 Perean Kangin is a partner in the Community Partnership Program, which is one of the state primary schools located in the Baturiti Tabanan area, where the environment around the school is still a beautiful rural environment with little technological development. The problem faced is the lack of awareness of the potential of organic waste contained in their environment, and knowledge of the importance of sorting rubbish, which still piles up various types of garbage in one trash can. The purpose of this activity is to increase awareness and increase students' knowledge and skills to sort and manage waste, especially organic waste. The presentation method is used to describe in general the concept of waste segregation and by staying interactive with students. The material presented is the difference between organic and inorganic waste, and how to use it according to the type of waste, and the results of organic waste management. The results of activities that have been carried out are the presentation of material on organic and inorganic waste, as well as training in making compost as a result of organic waste processing. Based on the activities that have been carried out students are able to sort waste according to its type.
\end{abstract}

Keywords: Environment, Community Partnership Program, Waste, Compost Fertilizer.

\begin{abstract}
Abstrak
SD Negeri 1 Perean Kangin adalah mitra dalamProgram Kemitraan Masyarakat yang merupakan salah satu sekolah dasar negeri yang terdapat di daerah Baturiti Tabanan, dimana lingkungan disekitar sekolah merupakan lingkungan pedesaan yang masih asri dengan terpengaruh sedikit perkembangan teknologi. Masalah yang dihadapi adalah kurangnya kesadaran terhadap potensi sampah organik yang terdapat di sekitar lingkungan mereka, dan pengetahuan tentang pentingnya pemilahan sampah, yang masih menumpuk sampah berbagai jenis dalam 1 tempat sampah. Tujuan kegiatan ini adalah untuk meningkatkan kesadaran dan menambah pengetahuan dan keterampilan siswa untuk memilah dan mengelola sampah khususnya sampah organik. Metode presentasi digunakan untuk menjabarkan secara umum konsep pemilahan sampah dan dengan tetap interaktif dengan siswa. Adapun materi yang disampaikan adalah perbedaan sampah organik dan an organik, serta cara pemanfaatannya sesuai dengan jenis sampah, dan hasil dari pengelolaan sampah organik. Hasil kegiatan yang sudah dilaksanakan adalah pemaparan materi tentang sampah organik dan an organik, serta pelatihan pembuatan pupuk kompos sebagai hasil dari pengolahan sampah organik. Berdasarkan kegiatan yang sudah dilakukan siswamampu untuk memilah sampah sesuai dengan jenisnya.

Kata Kunci: Lingkungan, Program Kemitraan Masyarakat, Sampah, Pupuk Kompos.
\end{abstract}

\section{PENDAHULUAN}

SD Negeri 1 Perean Kangin adalah salah satu sekolah dasar di Perean Kangin yang berlokasi di Br. Anyar Perean Kangin. Saat ini, jumlah siswanya sebanyak 80 orang yang terbagi ke dalam enam (6) tingkat, masing-masing satu rombongan belajar. Saat ini para siswa masih sering salah dalam hal memilah sampah saat membuang sampah pada tempatnya. Pemilahan sampah ini bertujuan untuk mempermudah proses pemanfaatan kembali sampah sesuai dengan jenisnya ${ }^{1}$.

\footnotetext{
${ }^{1}$ Indriyanti, D. R., Banowati, E., dan Margunani. 2015. Pengelolaan Limbah Organik Sampah Pasar Menjadi Kompos. Abdimas, 19(1): 43-44.
} 
Sampah itu sendiri terbagi menjadi 2 jenis yakni Sampah Organik dan Anorganik. Tentu kedua jenis ini memiliki perbedaan baik dari segi bentuk serta cara pengolahannya dan juga manfaatnya. Sampah Organik Merupakan Sampah/Limbah yang berasal dari sisa makhluk hidup yang ada di alam di antaranya seperti tumbuhan dan hewan, serta beberapa macam hasil dari olahan dan kemudian di buang dan kemudian terurai secara alami oleh bakteri tanpa perlu adanya capuran bahan kimia apapun dalam melakukan proses penguraian. Dengan kata lain Sampah organic ini adalah sampah yang ramah lingkungan dan biasanya bisa di manfaatkan kembali dengan melakukan pengolahan yang tepat serta pemanfaatannya di antaranya seperti Pupuk Kompos dan berbagai macam untuk makanan ternak. Walaupun tidak berbahaya, akan tetapi untuk pengolahan sampah organik yang tidak tepat akan menyebabkan timbulnya berbagai macam masalah bagi kehidupan manusia, hal tersebut tentunya dapat saja terjadi mengingat sampah organic sangat mudah mengalami pembusukan. Sehingga dengan proses cepatnya membusuk tersebut dapat menciptakan atau menyebarnya berbagai penyakit dan bakteri terhadap lingkungan yang tidak mempunyai system pengolahan sampah yang baik ${ }^{2}$.

Berbeda dengan sampah Organik dimana Sampah anorganik adalah salah satu masalah terbesar yang hingga kini di dapat anda temukan di tengah masyarakat yang menyebabkan terjadinya dampak buruk bagi kehidupan manusia. Hal tersebut disebabkan dari banyaknya sampah anorganik yang ada di sekeliling lingkungan kita dan mencemari lingkungan hidup karena sampah jenis ini tidak dapat terurai secara alami dalam waktu yang singkat. Butuh waktu yang sangat lama sekitar ratusan hingga ribuan tahun agar sampah anorganik dapat terurai. Beberapa contoh dari sampah anorganik: Plastik, kaca, kaleng, besi, dan yang lainnya ${ }^{3}$.

Berdasarkan hasil pengamatan dan observasi, didapatkan fakta bahwa kesadaran siswa terhadap potensi yang dimiliki oleh sampah organik masih kurang. Padahal, sampah organik di sekitar lingkungan mereka sangatlah banyak serta lingkungan mereka yang dekat dengan pertanian dan perkebunan sangatlah bagus untuk penerapan manfaat sampah organik. Kendala yang dihadapi adalah masih adanya anggapan buruk tentang sampah, serta kurang aktifnya peran serta dan dukungan guru untuk mendorong siswanya agar lebih peduli dan sadar terhadap kondisi lingkungan mereka. Upaya yang dilakukan sampai saat ini adalah dengan melakukan kegiatan bersih - bersih akan tetapi sampah yang dibersihkan hanya dibuang ke tempat sampah saja.

Kegiatan pengabdian ini penting untuk dilaksanakan karena para siswa merupakan generasi yang tumbuh di era revolusi industry 4.0 sehingga sangat penting untuk menanamkan semangat cinta lingkungan melalui pengetahuan pemanfaatan

\footnotetext{
${ }^{2}$ Kuncoro Sejati. 2009. Pengolahan Sampah Terpadu. Yogyakarta: Kanisius.

3 Ruhiyat, D., Indrawati, D., Indrawati, E., dan Siami, L. 2018. Program Kemitraan Masyarakat Kelompok Pemanfaat Kotoran Hewan (KOHE) dan Kelompok Tani Organik. Jurnal Pengabdian Kepada Masyarakat Universitas Kuningan (Empowerment), Jakarta
} 
sampah organik sehingga kedepannya mereka dapat menikmati lingkungan yang lebih bersih dan sehat.

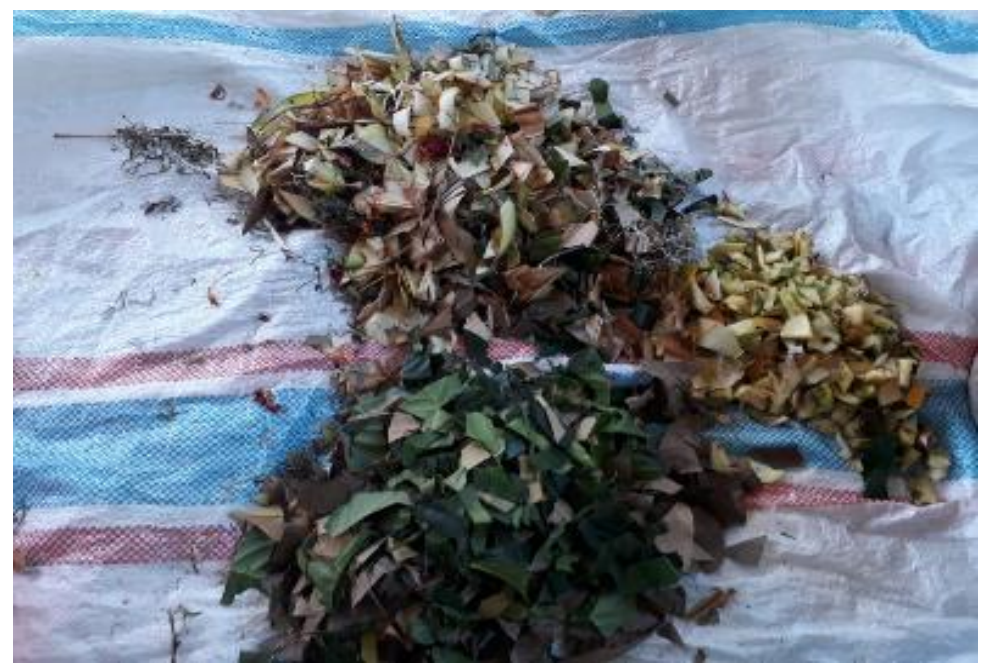

Gambar 1. Gambaran potensi sampah organik di sekitar lingkungan SD Negeri 1 Perean Kangin

Pemaslahannya yaitu mengacu pada uraian analisis situasi persoalan prioritas pada SD Negeri 1 Perean Kangin maka dilakukan sosialisasi tentang pengolahan sapah Organik untuk dijadikan pupuk. Hal ini dilakukan sebab kurangnya pemberian informasi tentang manfaat, pengolahan sampah organik dan contoh penerapannya pada semua siswa yang bersekolah di SD ini.

\section{METODE PELAKSANAAN}

Kegiatan penerapan Program Kemitraan Masyarakat (PKM) bertujuan untuk memberikan pengetahuan kepada siswa tentang pentingnya mengelola dan memilah sampah di sekitar lingkungan serta mampu untuk melakukan pemnfaatan sampah organik menjadi pupuk kompos pada kelompok siswa dan siswi SD Negeri 1 Perean Kangin melalui pengenalan jenis sampah, bahaya, serta manfaatnya bila diolah. Dengan mengedepankan metode komunikatif dan dengan memahami pola pikir dari siswa SD sehingga materi yang disampaikan dapat diterima dengan baik oleh siswa. Metode komunikatif partisipatif dimaksudkan agar siswa mau memperhatikan sehingga penyampaian materinya dapat diterima dengan baik oleh siswa.

Metode pelaksanaan yang digunakan dalam Program Kemitraan Masyarakat (PKM) ini adalah sebagai berikut:

1. Presentasi pengenalan materi perbedaan sampah organik dan an organik. Metode ini dipilih karena menarik untuk siswa SD dan sebagai tahap awal pengenalan tentang perbedaan sampah serta bahaya dan manfaatnya.

2. Presentasi produk berupa pupuk kompos. Metode ini dipilih untuk menarik perhatian siswa dengan menampilkan contoh produk nyata hasil pengolahan dan pemanfaatan sampah khusunya sampah organik yang banyak terdapat di sekitar 
lingkungan SD Negeri 1 Perean Kangin.

3. Pelatihan Pembuatan Pupuk kompos. Metode ini dipilih karena merupakan metode yang paling mudah untuk dipraktekkan dalam pengelolaan sampah organik. Selain itu pula menyangkut kondisi di sekitar lingkungan SD Negei 1 Perean Kangin yang memiliki sampah organik yang lumayan, sehingga memudahkan untuk mencari bahan baku dari pupuk kompos tersebut.

\section{HASIL DAN PEMBAHASAN}

Adapun program dan kegiatan pengabdian kepada masyarakat dalam Program Kemitraan Masyarakat (PKM) yang sudah dilaksanakan adalah sebagai berikut:

\section{Persiapan dan Sosialisasi Program Kemitraan Masyarakat (PKM)}

Tim pengabdian masyarakat melakukan koordinasi tentang program pengabdian kepada mitra dan menginformasikan tentang tahapan/jenis kegiatan yang akan dilaksanakan, peran masing-masing pihak dan hasil yang ingin dicapai. Hal ini juga dimaksudkan agar mitra mengetahui tujuan dari kegiatan PKM ini dan juga persiapan yang dilakuakan oleh mitra maupun tim PKM untuk menyukseskan kegiatan PKM ini dan serta meminta dukungan dan kerjasama yang baik agar apa yang menjadi tujuan dari pelaksanaan PKM dapat dicapai.

\section{Presentasi tentang pemilahan dan pemanfaatan sampah}

Presentasi tentang pemilahan dan pemanfaatan sampah berisi materi tentang perbedaan jenis sampah, dimana jenis sampah secara umum dapat dibedakan menjadi 2 yaitu sampah organik dan an organik. Dimana kedua jenis sampah tersebut memilik cara penanganan yang berbeda, serta memiliki bahaya yang berbeda, untuk itu dijabarkan materi secara komunikatif bagaimana perbedaan sampah organik dengan an organik, serta cara memilah sampah tersebut saat akan dibuang sehingga nantinya sampah tersebut dapat degan mudah diolah atau didaur ulang.

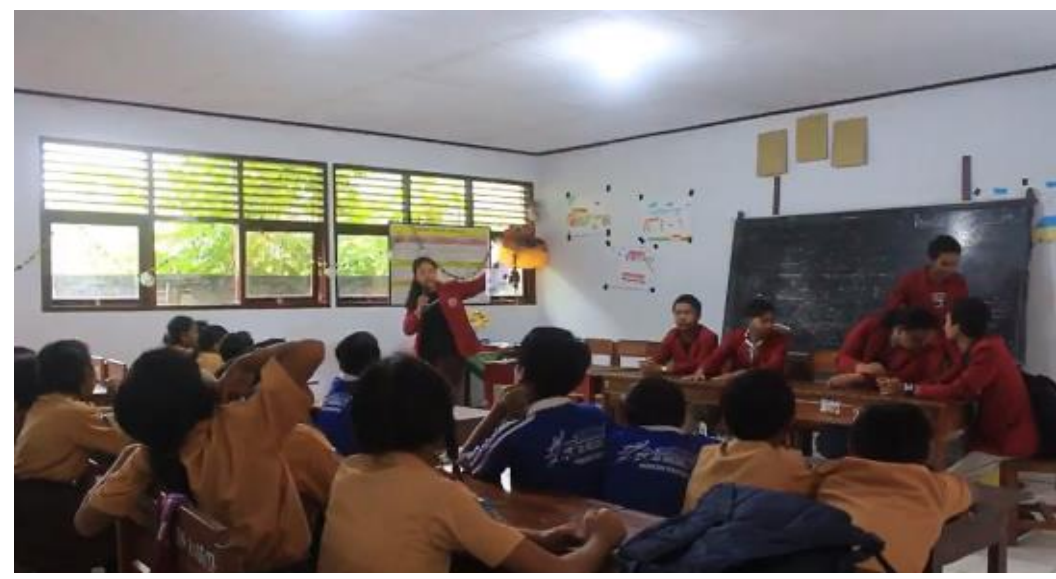

Gambar 2. Presentasi jenis sampah 


\section{Presentasi pupuk kompos sebagai hasil dari pengolahan sampah organik}

Presentasi pupuk kompos dilakukan untuk memberikan gambaran tentang bagaimana hasil dari pemanfaatan kembali sampah khususnya sampah organik kepada para siswa. Sehingga para siswa menjadi tertarik untuk belajar memanfaatkan sampah organik yang banyak terdapat disekitar lingkungan mereka. Dengan demikian informasi yang didapatkan di awal di saat presetasi materi jenis sampah akan dapat dipergunakan dengan baik oleh para siswa. Presentasi ini juga memberikan pemahaman bahwa pupuk kompos yang sudah siap memiliki manfaat yang sangat besar, dan juga menunjukan ciri - ciri dari suatu pupuk organik khusus nya pupuk kompos.

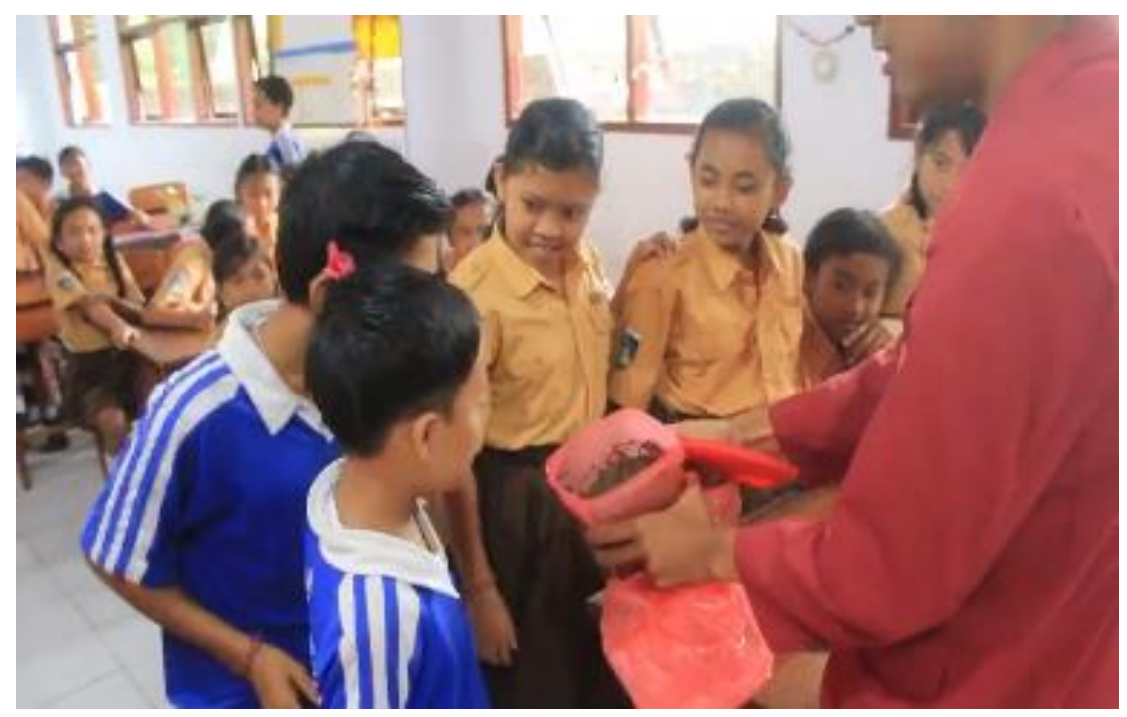

Gambar 3. Presentasi contoh pupuk kompos

\section{Pelatihan pembuatan pupuk kompos}

Pelatihan pembuatan pupuk kompos berupa pemberian langkah - langkah pembuatan pupuk kompos kepada para siswa. Pada pelatihan ini ditampilkan alat - alat sederhana yang terdapat di sekitar lingkungan mereka sebagai media untuk membuat pupuk kompos. Dengan bahan utamanya berupa sampah daun dan bekas canang yang banyak di sekitar lingkungan SD Negeri 1 Perean Kangin. Pelatihan ini juga untuk mengajarkan pentingnya penggunaan pupuk organik untuk tanaman yang terutama tanaman yang merupakan bahan pangan untuk konsumsi manusia. Pada tahap pelatihan ini siswa diajak kembali untuk mengingat jenis sampah apa yang bisa digunakan untuk pembuatan pupuk kompos, dan bagaimana cara serta berapa hari rentang pupuk kompos itu siap digunakan setelah semua komponen yang diperlukan seperti sampah organik (daun, ranting kering, dll.) tanah, dicampur kemudian ditutu dalam toples atau wadah yang kedap udara ${ }^{4}$.

\footnotetext{
${ }^{4}$ Ni Komang Ayu Artiningsih. 2008. Peran Serta Masyarakat dalam Pengelolaan Sampah Rumah Tangga, Universitas Diponegoro, Semarang.
} 


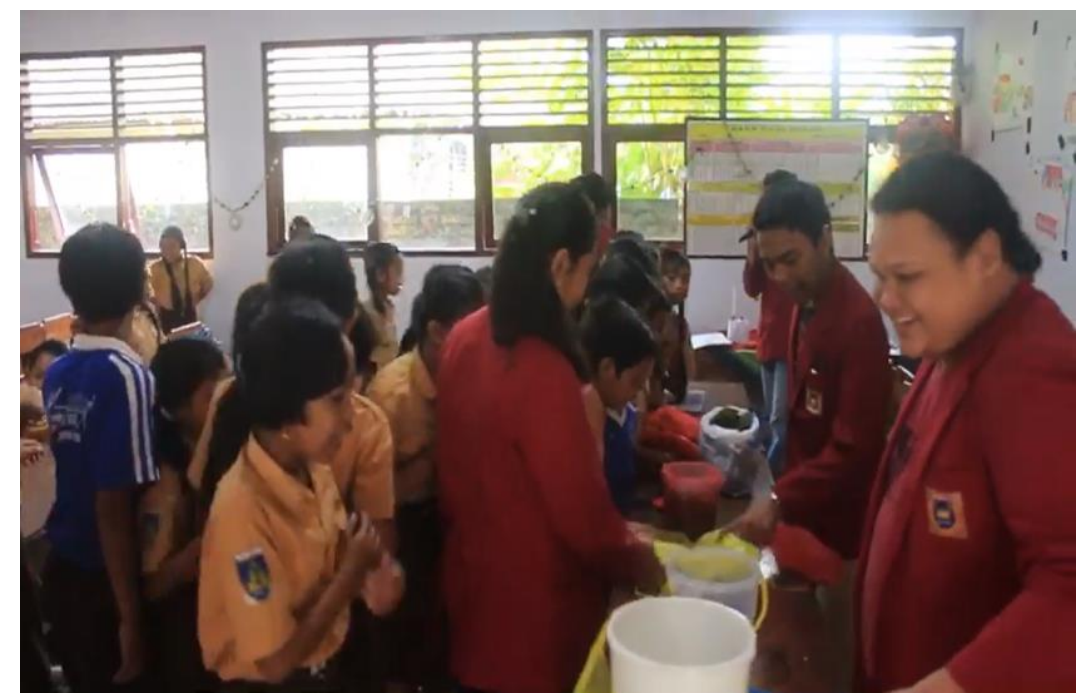

Gambar. 4 Pelatihan pembuatan pupuk kompos

\section{Pengaplikasian contoh pupuk kompos pada tanaman}

Contoh pupuk kompos yang telah dibuat sebelumnya yang digunakan sebagai media presentasi hasil dari pengelolaan sampah organik, ditaburkan atau diaplikasikan pada tanaman yang terdapat di kebun sekolah. Hal ini bertujuan untuk memberikan contoh nyata kepada siswa bahwa pupuk yang sudah siap dapat langsung dipakai untuk menyuburkan tanaman, dan memberikan informasi kepada siswa bahwa pupuk organik terutama kompos akan menyuburkan tanah, sehingaa tanaman yang diberikan pupuk organik akan subur dan menyehatkan apabila itu merupakan tanaman pangan ${ }^{5}$.

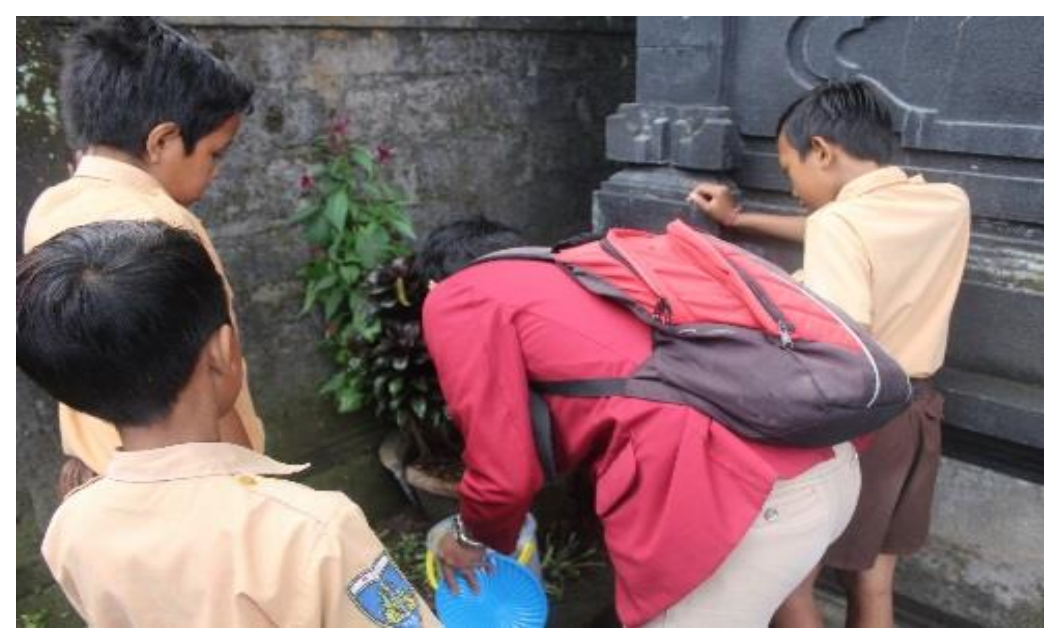

Gambar 5. Pengaplikasian pupuk kompos pada tanaman kebun sekolah

\footnotetext{
5 Setyawati, S., Suparmini, Sumunar, D., dan Khotimah, N. 2014. Pelatihan Pengelolaan Sampah Anorganik Menjadi Aneka Kreasi Daur Ulang. Yogjakarta.
} 


\section{SIMPULAN}

Berdasarkan kegiatan Program Kemitraan Masyarakat (PKM) ini maka dapat disimpulkan sebagai berikut:

1. Kesadaran para siswa terhadap pentingnya pengelolaan sampah cukup kurang

2. Antusias dari para siswa terhadap "Sosialisasi Pengolahan Sampah Organik" yang kami lakukan sangat baik.

3. Para siswa sangat aktif dalam bertanya ataupun menjawab pertanyaan yang kami berikan kepada mereka.

\section{SARAN}

Sedangkan saran yang dapat disampaikan mengenai kegiatan Program Kemitraan Masyarakat (PKM) ini ialah sebagai berikut:

1. Kegiatan ini diharapkan dapat dilakukan secara berkala dan berkesinambungan di tempat lainnya melihat antusiasme peserta.

2. Kegiatan ini juga diharapkan dapat digarap dengan serius sehingga dapat memberi alternatif usaha pada masyarakat sekitar untuk dapat menigkatkan taraf kehidupannya dan menjadi lebih sejahtera, seperti yang dilakukan oleh kelompok PKM pemanfaatan KOHE di Cibodas dan Cisondari.

3. Jangka waktu yang dibutuhkan oleh tim Program Kemitraan Masyarakat (PKM) STMIK STIKOM Indonesia adalah lebih lama, sehingga dapat kegiatan berjalan lebih maksimal.

\section{UCAPAN TERIMA KASIH}

Penulis menyampaikan terima kasih kepada STMIK STIKOM Indonesia atas kesempatannya serta ijinnya untuk melaksanakan kegiatan Program Kemitraan Masyarakat (PKM) ini. Terimakasih juga Sekolah Dasar Negeri 1 Perean Kangin yang sudah berkenan menjadi mitra kegiatan Program Kemitraan Masyarakat (PKM) ini dan sudah memfasilitasi dan mendukung kegiatan Program Kemitraan Masyarakat (PKM) ini, serta seluruh jajaran guru serta siswa terlibat dalam kegiatan pengabdian ini.

\section{DAFTAR PUSTAKA}

Indriyanti, D. R., Banowati, E., dan Margunani. 2015. Pengelolaan Limbah Organik Sampah Pasar Menjadi Kompos. Abdimas, 19(1): 43-44.

Kuncoro Sejati. 2009. Pengolahan Sampah Terpadu. Yogyakarta: Kanisius.

Ni Komang Ayu Artiningsih. 2008. Peran Serta Masyarakat dalam Pengelolaan Sampah Rumah Tangga, Universitas Diponegoro, Semarang.

Ruhiyat, D., Indrawati, D., Indrawati, E., dan Siami, L. 2018. Program Kemitraan

Masyarakat Kelompok Pemanfaat Kotoran Hewan (KOHE) dan Kelompok Tani

Organik. Empowerment : Jurnal Pengabdian Masyarakat, e-ISSN 2598-2052 Vol. 01 Nomor 01. 2018.79-88

Setyawati, S., Suparmini, Sumunar, D., dan Khotimah, N. 2014. Pelatihan Pengelolaan Sampah Anorganik Menjadi Aneka Kreasi Daur Ulang. Yogjakarta. 